\title{
A taxonomic revision of the tribe Oryzeae (Poaceae) in Thailand
}

\author{
Paweena Traiperm $^{\mathrm{a}, *}$, Monthon Norsaengsri ${ }^{\mathrm{b}}$, Stephan W. Gale ${ }^{\mathrm{c}}$ \\ a Department of Plant Science, Faculty of Science, Mahidol University, Rama 6 Road, Rachathewi, \\ Bangkok 10400 Thailand \\ b Maejo University Phrae Campus 17 Moo 3, Maesai, Rongkwang, Phrae, Thailand 54140 \\ c Kadoorie Farm \& Botanic Garden, Lam Kam Road, Tai Po, New Territories, Hong Kong
}

*Corresponding author, e-mail: paweena.tra@mahidol.edu

Received 24 Dec 2014

Accepted 14 Dec 2015

ABSTRACT: The tribe Oryzeae is represented in Thailand by nine species (one with two varieties) in four genera. Keys to all taxa are provided together with descriptions, illustrations, photos, ecological data and notes, including IUCN conservation assessments. The single endemic species, Leersia stipitata Bor, is regarded as globally critically endangered, whereas all other more widely distributed species are not found to be threatened in Thailand. Two names are typified: Pharus ciliatus Retz. and Oryza meyeriana (Zoll. \& Moritzi) Baill. var. granulata (Nees \& Arn. ex G. Watt) Duist.

KEYWORDS: conservation status, Hygroryza, Leersia, Oryza, Zizania

\section{INTRODUCTION}

The tribe Oryzeae Dumort. belongs to the grass family (Poaceae) and comprises around seventy species in eleven genera distributed in tropical and warm temperate parts of the world ${ }^{1}$. Its most well known member is Oryza sativa, a domesticated cereal and one of the world's most important staple foods, but it also includes other economic species, including Zizania latifolia (Griseb.) Turcz. ex Stapf, another popular cereal and vegetable crop ${ }^{1,2}$. Most genera of the tribe grow in aquatic environments, although a few occur in forests ${ }^{2}$.

Because of its economic importance, the taxonomy and morphology of rice and closely related genera have been studied in several regions, including China ${ }^{3}$, Myanmar ${ }^{4}$, Sri Lanka ${ }^{5,6}$, India and Pakistan $^{4}$, Malaysia, and Australia ${ }^{7}$. In Thailand, the tribe has been treated in a checklist that enumerated eleven species (one with two varieties) in four genera (namely, Oryza L., Leersia Sw., Hygroryza Nees and Zizania L.), but this lacked a key to the species and taxonomic descriptions, leading to misidentification $^{8}$. More recently, a key to the Thai species using lemma micromorphology was published ${ }^{9}$, but that study was unable to provide resolution within a species complex comprising O. officinalis Wall. ex G. Watt, O. rufipogon Griff., and O. sativa. Moreover, taxonomic information and descriptions crucial to an understanding of the tribe in Thailand are miss- ing. The present study therefore set out to provide a complete taxonomic account of Thai Oryzeae, in advance of its treatment in the Flora of Thailand series.

\section{MATERIALS AND METHODS}

We examined specimens pertaining to all taxa of tribe Oryzeae collected in Thailand and held at the following herbaria: $\mathrm{AAU}, \mathrm{BK}, \mathrm{BKF}, \mathrm{BM}, \mathrm{C}, \mathrm{K}$, $\mathrm{K}-\mathrm{W}, \mathrm{KKU}, \mathrm{L}$, and QBG. In addition, we consulted the digitised specimens held at LD, LE, LINN, P, S, SING and $U$ that are available online. In total, 308 specimens were examined. Observations were also made of fresh materials of nine taxa collected from several locations in Thailand during the course of this study. Type specimens were verified directly at the herbaria visited where possible, or from digital images available online if necessary, and relevant literature was consulted. The conservation status of all taxa in Thailand was assessed against IUCN criteria B (geographic range) and D (very small or restricted population) ${ }^{10}$. All herbarium collections examined were georeferenced, and GPS coordinates were recorded for all subpopulations visited in the field. Extent of occurrence (EOO) and area of occupancy (AOO) of each species were estimated in GeoCAT $^{11}$. For AOO, a $2 \times 2 \mathrm{~km}$ grid cell size was used. The species' ecological attributes (including inferred habitat requirements and reproductive biology), number and distribution of locations, esti- 
mated population size, known or inferred threats, and the degree to which the populations have undergone, or are projected to undergo decline, were also considered ${ }^{10}$. The assessment conducted in this manner for the strict endemic Leersia stipitata Bor constituted a full global assessment, but for all other, more widespread taxa, this "preliminary assessment" was subject to a further round of verification following the guidelines for the application of IUCN criteria at the regional level ${ }^{12}$.

\section{TAXONOMIC TREATMENT}

\section{Oryzeae}

Dumort. Observ. Gramin. Belg. 83: 135. 1824. Zizanieae Hitchc., Gen. grasses U.S. 18: 1920.

Annual or perennial herbs. Leaf-blades usually linear to lanceolate; ligule membranous. Inflorescence a panicle with simple raceme-like primary branches. Spikelets 1 or 3-flowered with 2 lower sterile lemmas. Glumes absent or reduced to 2 tiny lobes on the tip of the pedicel. Lemma membranous to coriaceous, with or without a straight awn. Palea similar to lemma. Lodicule 2. Stamens 6. Stigmas 2, plumose. Caryopsis oblong or terete.

About eleven genera distributed in tropical and warm temperate regions of the world ${ }^{1}$. Only 4 genera occur in Thailand: Hygroryza, Leersia, Oryza and Zizania ${ }^{8,9}$. See Table 1.

\section{Hygroryza}

Nees in Edinburgh New Philos. J. 15: 380. 1833; Bor, Grasses Burma, Ceylon, India \& Pakistan 597. 1960; Phan. Mono. Tom. 12: 181. 1980; Fl. Ceylon 8: 257. 1994; Fl. China 22: 186. 2006; Fl. North America 24: 46. 2007. Type species: H. aristata (Retz.) Nees ex Wight \& Arn. in Edinburgh New Philos. J. 15: 380. 1833. - Potamochloa Griff. in J. Asiat. Soc. Bengal 5: 571. 1836, nom. illeg. superfl.

Perennial, aquatic, stoloniferous herbs. Culms floating with adventitious roots. Leaf sheaths inflated, spongy; leaf blades ovate-lanceolate or

Table 1 Key to genera of Oryzeae in Thailand.

\begin{tabular}{ll}
\hline $\begin{array}{l}\text { 1. Leaf blades ovate-lanceolate or } \\
\text { broadly lanceolate }\end{array}$ & Hygroryza \\
1. Leaf blades narrow linear, linear, or & \\
lanceolate & \\
2. Spikelets unisexual & Zizania \\
2. Spikelets bisexual & \\
3. Sterile lemmas present & Oryza \\
3. Sterile lemmas absent & Leersia \\
\hline
\end{tabular}

broadly lanceolate. Inflorescence a panicle, enclosed by uppermost leaf sheath. Spikelets 1-flowered. Glumes absent. Lemma membranous, 5-nerved, keeled, awned. Palea smaller and shorter than lemma, 3-nerved. Caryopsis terete.

Hygroryza is a monotypic genus represented only by $H$. aristata, an aquatic plant with ovate or lanceolate floating leaf blades and inflated leaf sheaths. This species occurs in Pakistan, India, Sri Lanka, Bangladesh, Nepal, Myanmar, South China and Taiwan, Thailand, Laos, Cambodia and Vietnam $^{13}$.

1. Hygroryza aristata (Retz.) Nees ex Wight \& Arn. in Edinburgh New Philos. J. 15: 380. 1833; Hook. f. in Trimen, Handb. Fl. Ceylon 5: 185. 1900; Bor, Grasses Burma, Ceylon, India \& Pakistan 597. 1960; Phan. Mono. Tom. 12: 181. 1980; Fl. Ceylon 8: 257. 1994; Fl. China 22: 186. 2006; Fl. North America 24: 46. 2007; Pharus aristatus Retz. Observ. Bot. 5: 23. 1789. Type: without locality, s. coll. s.n. (lectotype LD!); Zizania aristata (Retz.) Kunth, Révis. Gramin. 1: 8. 1829; Leersia aristata (Retz.) Roxb., Fl. Ind. ed. 2(2): 308. 1832.-Z Z retzii Spreng. Syst. Veg. 2: 136. 1825, nom. illeg. superfl.- Potamochloa retzii Griff. in J. Asiat. Soc. Bengal 5: 571. 1836, t. 24, nom. illeg. superfl. Fig. 1A,B, Fig. 2.

Culms $15-100 \mathrm{~cm}$ long, floating in water or decumbent on mud in the dry season. Leaf sheath 2-6 cm long, glabrous; ligule c. $0.5 \mathrm{~mm}$ long, truncate; leaf blade $2-7 \times 1-2.8 \mathrm{~cm}$, adaxial surface papillate or scabrous, base rounded to cordate, apex obtuse. Inflorescence triangular in outline, with 4 or 5 major branches, whorled at apex of peduncle, base enclosed by uppermost leaf sheath. Spikelet bisexual, 1-flowered. Glume absent. Lemma 10$18 \mathrm{~mm}$ long, boat-shaped, coriaceous, 5-nerved, hispid-ciliate along nerves, apex tapering to a long, stout, straight awn. Paleas $6-8 \mathrm{~mm}$ long, very similar to the lemma but thinner and shorter, muticous, hispid between nerves. Caryopsis narrowly oblong, obtuse, turgid, cylindric; hilum linear, as long as grain, rather faint.

Thailand.- NORTHERN: Chiang Mai, Mae Rim, 18 Oct. 2005, W. La-ongsri \& Prasong 354 (QBG); Phayao, 2 Mar. 1958, Th. Sørensen, K. Larsen \& B. Hansen 1827 (BKF, C, K, L); Phitsanulok, Thung Salaeng Luang, 19 Jul. 1966, K. Larsen, T. Smitinand \& E. Warncke 511 (BKF); CENTRAL: Bangkok, 7 Dec. 1919, Kerr 3883 (BK, BM, K); Bangkok Noi, 3 Feb. 1954, T. Smitinand 1541 (BKF); SOUTH-EASTERN: Rayong, Chak Phong subdistrict, 

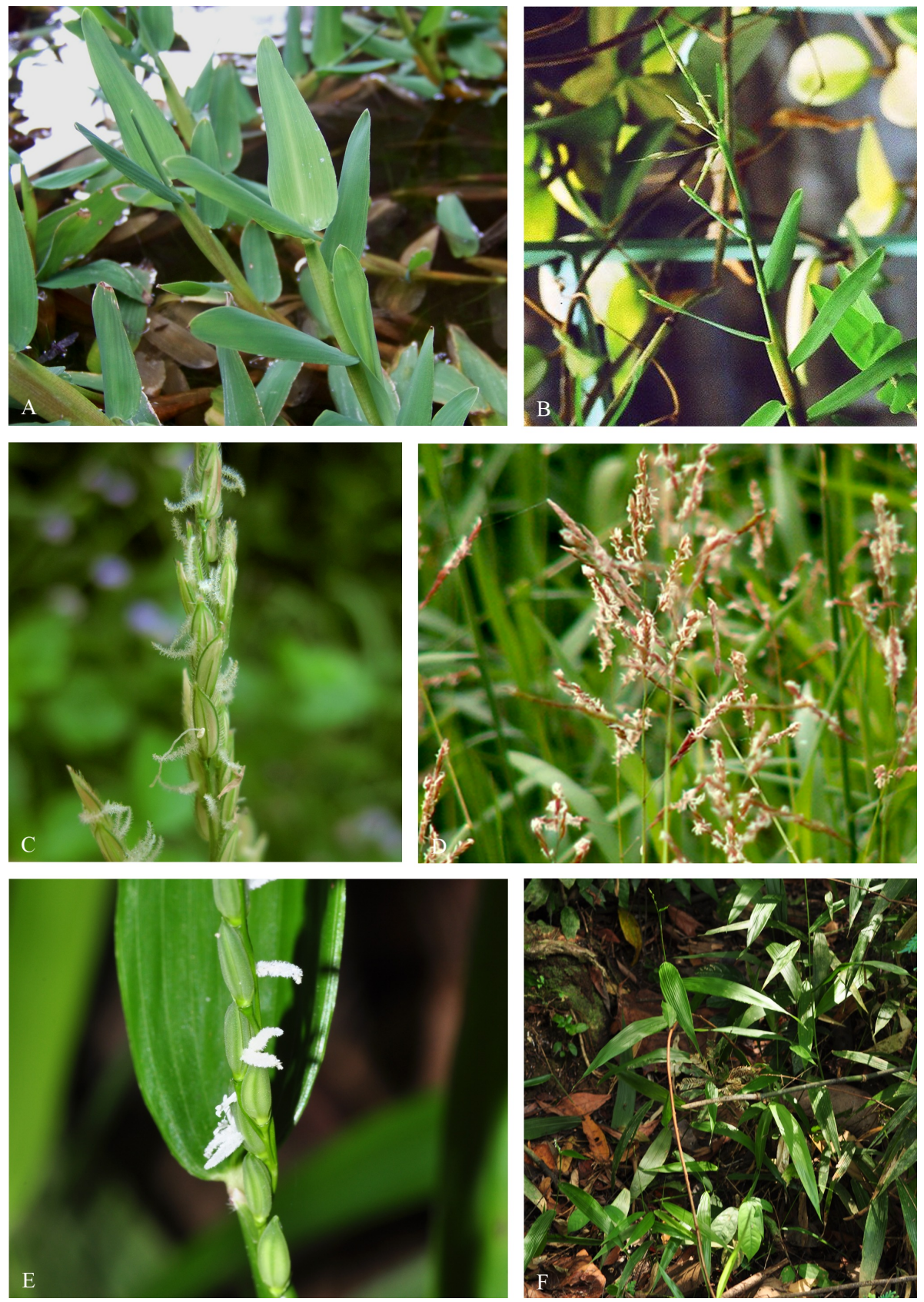

Fig. 1 (A,B) Hygroryza aristata (Retz.) Nees ex Wight \& Arn.: (A) habit; (B) inflorescence, (photos: Haruthai Hemadhulin). (C,D) Leersia hexandra Sw.: (C) inflorescence; (D) habit, (photos: Woranart Thammarong). (E,F) Oryza meyeriana (Zoll. \& Moritzi) Baill. var. meyeriana: (E) inflorescence; (F) habit, (photos: Phanom Sutthisaksopon).

Klaeng, 6 May 2009, P. Wessumritt \& M. Norsaengsri 203 (QBG); Chanthaburi, Makam, 14 Jun. 1963, K. Larsen 10087 (BKF, C), 10087a (K); Trat, Koh Chang, 22 Feb. 1985, T. Smitinand s.n. (BKF); PENINSULAR: Phatthalung, Tale Noi, 1 Apr. 2012, Sumanon \& Traiperm 2 (BKF); Songkhla, 8 Apr. 1928, Kerr 15119 (BK, BM, K), 28 Dec. 1978, Hamil- ton \& Congdon 157 (BKF).

Distribution.- This species also occurs in India, Myanmar, China, Malaysia and Indonesia.

Habitat and Ecology.- Forming large floating mats in small ponds, pools and canals, from sea level to $50 \mathrm{~m}$ elevation. Flowering throughout the year.

Vernacular name.-Ya-phong-lom. 


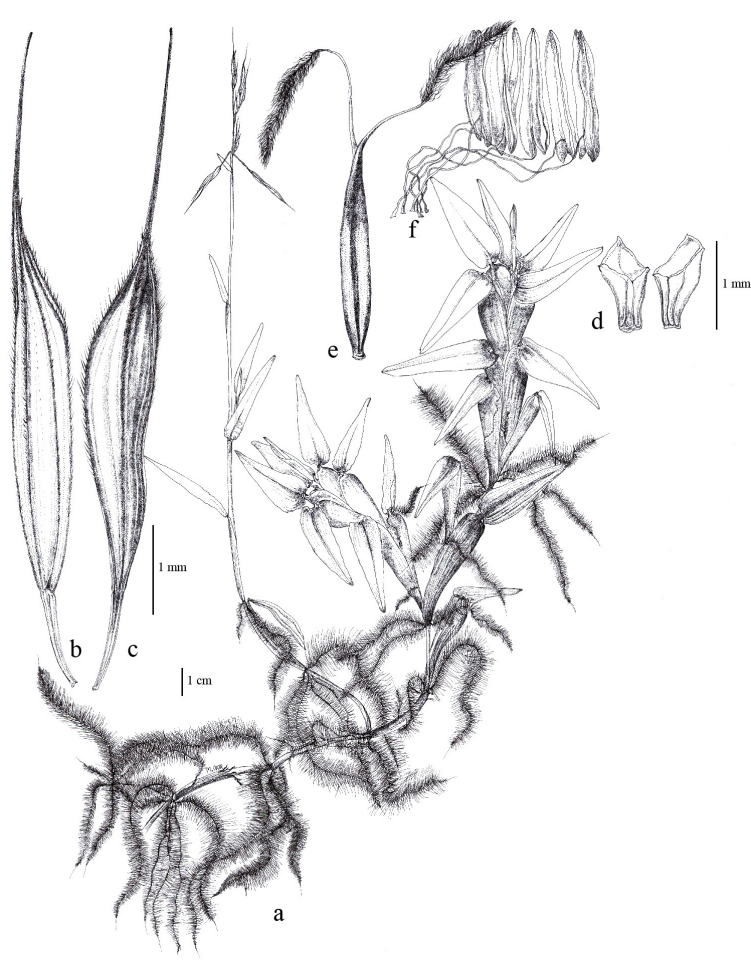

Fig. 2 Hygroryza aristata (Retz.) Nees ex Wight \& Arn.: (a) habit; (b) lemma; (c) palea; (d) lodicules; (e) pistil; (f) anthers. Drawn by M. Norsaengsri.

Uses.- Widely cultivated by local people for its grain, which is used as fodder for livestock during cold weather ${ }^{4,14}$. In Thailand it is also cultivated as an ornamental aquatic plant.

Conservation status.- Eleven herbarium collections of this species in Thailand were examined, and it was observed during field work at one additional locality. Based on these records, $H$. aristata was found to have an EOO of $255912 \mathrm{~km}^{2}$ and an AOO of $44 \mathrm{~km}^{2}$. Although the species has a scattered distribution in Thailand, its subpopulations are not severely fragmented; it is very widespread throughout the region. Subpopulations can grow rapidly via vegetative propagation and typically comprise numerous shoots. It is not known whether any single site constitutes only a single clone or multiple, genetically distinct individuals, making it difficult to estimate the true population size in Thailand. The origin of cultivated plants in Thailand and their potential for introgression with native genotypes is unknown. Some known locations for this species are being developed as tourist attractions, but at present there are no known specific threats to the species in Thailand. The degree of connectivity with subpopulations in neighbouring countries is expected to be high. Accordingly, it is regarded as least concern (LC) in Thailand.

Notes.- Anders Jåhan Retzius's original description of this taxon, published in his Observationes Botanicae in 1789, was based on Koenig's collections from India. Koenig's holotype should be held at $\mathrm{C}$, but despite a thorough search, we were unable to locate any Koenig specimens for this taxon at that herbarium. Recognizing the same problem, Turner ${ }^{15}$ earlier designated a collection at LD without locality, collector, or number as the lectotype. However, duplicates of Koenig's original material were sent out to several herbaria; we found one sheet at BM (barcode number BM000959315) that is better preserved than Turner's lectotype, and which bears an original hand-written note confirming its origin as India. We have been unable to confirm whether this was written by Koenig himself, but we feel this specimen would have made a better choice for lectotypification.

\section{Leersia}

Sw., Prodr. 21. 1788, nom cons.; Bor, Grasses Burma, Ceylon, India \& Pakistan 599. 1960; Fl. China 22: 184. 2006. Type species: L. oryzoides (L.) Sw., Prodr. 21. 1788.- Homalocenchrus Mieg in Acta Helv. Phys. Math. 4: 307. 1760, nom. rejec. Type species: H. oryzoides (L.) Pollich in Hist. Pl. Palat. 1: 52. 1776.- Ehrhartia F.H. Wigg., Prim. Fl. Holsat. 63. 1780, nom illeg. superfl.Asprella Schreb., Gen. Pl. ed. 8: 45. 1789, nom illeg. superfl._L Laertia Gromov Trudy Obsc. Nauk. Kharkow Univ. 1: 141. 1817, nom illeg. superfl.

Annual or perennial herbs. Culms slender, erect or decumbent, rooting at nodes. Leaf sheaths tight, not inflated, smooth, or scabrid; leaf blades linearacute. Inflorescence a panicle or sometimes racemose and enclosed within the sheath. Spikelets 1floret, bisexual, flattened. Glumes absent. Lemma awned or awnless. Sterile lemmas absent. Palea folded, nerved. Caryopsis not seen.

The genus of 18 species in tropical and warm temperate regions ${ }^{13}$, two species occur in Thailand. See Table 2.

1. Leersia hexandra Sw., Prodr. 21. 1788; Hook. F. in Trimen, Handb. Fl. Ceylon 5: 184. 1900; Bor,

Table 2 Key to species of Leersia in Thailand.

1. Lemma awnless

1. L. hexandra

1. Lemma awned

2. L. stipitata 


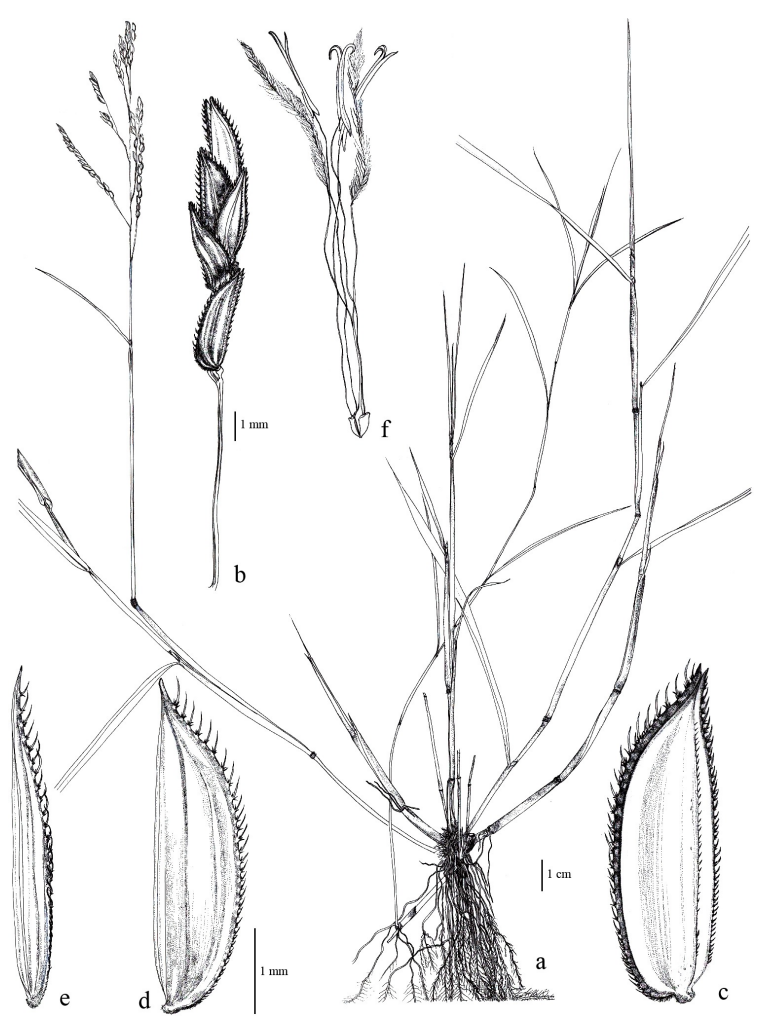

Fig. 3 Leersia hexandra Sw.: (a) habit; (b) inflorescence; (c) spikelet; (d) lemma; (e) palea; (f) lodicules, stamens, and pistil. Drawn by M. Norsaengsri.

Grasses Burma, Ceylon, India \& Pakistan 599. 1960; Phan. Mono. Tom. 12: 183. 1980; Fl. Ceylon 8: 295. 1994; Fl. China 22: 184. 2006; Fl. North America 24: 44. 2007; Fl. Australia 44A: 360. 2009. Type: Jamaica, Swartz s.n. (holotype S!; isotype BM!).- Leersia ciliata (Retz.) Roxb., Fl. Ind. 2nd edn, 2: 207. 1832; Pharus ciliatus Retz., Observ. Bot. 5: 23. 1789. Type: India, FG. Koenig s.n. (lectotype C!, designated here; isolectotypes BM!, K!, fragm.)._- Asprella australis (R.Br.) Roem. \& Schult., Syst. Veg. 2: 267. 1817; Leersia australis R.Br., Prodr. 210. 1810. Type: Australia, Keppel Bay, R. Brown 6170 (holotype BM!; isotypes BM!, K!, 2 sheets)._- Leersia mexicana Kunth in H.B.K., Nov. Gen. et Sp. 1, 195. 1816. Type: phototype taken from H.B.K. microfiche (K!). Fig. 1C,D, Fig. 3.

Perennial herb. Culms erect shoot up to $1 \mathrm{~m}$ tall, slender, decumbent, rooting at lower nodes, nodes pubescent. Leaf sheaths tight, smooth or scabrid, terete; ligule 1.5-4 mm long, glabrous, apex obtuse; leaf blades $0.4-1 \times 4-20 \mathrm{~cm}$, glabrous or glabrescent on both surfaces, margins rough. Inflorescence a panicle, branches slender. Spikelets 3-5 mm long, narrowly elliptic, elliptic to elliptic-oblong, flat, pale yellow, yellowish-green or tinged purple. Glumes absent. Lemma 1-1.3 × 3-5 mm, boat-shaped, with a subpectinately ciliate keel, margins scaberulous, awnless. Palea folded, shorter than the lemma, 3nerved, with a pectinately ciliate mid-nerve. Anthers yellow.

Thailand.- NORTHERN: Chiang Mai, 7 Nov. 1910, Kerr 1537 (BM); Doi Sutep, 18 Nov. 1911, Kerr 1537B (BM, K), 9 Nov. 1988, J.F. Maxwell 88-1299 (BKF, L); Doi Chiangdao, 2 Jul. 1958, K. Bunchuai \& C. Phengkhlai 926 (K, L); Mae Tang, 19 Oct. 1958, Th. Sørensen, K. Larsen \& B. Hansen 5777 (C, K); MaeJam, 20 Aug. 1985, J.F. Maxwell 85-789 (L); Mae Thaeng, 11 Aug. 1990, J.F. Maxwell 90874 (L); Doi Inthanon, 2 Oct. 1971, G. Murata et al T-15872 (BKF); Mae Klang waterfall, 5 Nov. 1965, P. Singkhachand 93 (BK); Bo Luang, 1 Feb. 1964, B. Hansen, G. Seidenfaden \& T. Smitinand 11013 (BKF, C, K), Nov. 1986, C. Phengklai \& T. Smitinand 6137 (AAU, BKF, K); Tak, Hard Palom, 20 Dec. 1961, K. Larsen 8847 (C); Lamphun, Doi Khun Tan National Park, 31 Oct. 1994, J.F. Maxwell 94-1169 (BKF, L); Phitsanulok, Thung Salaeng Luang, 23 Jul. 1966, K. Larsen, T. Smitinand \& E. Warncke 768 (AAU, K), 30 Sep. 1967, T. Shimizu T-11302 (BKF); Kamphaeng Phet, Muang, 12 Aug. 2012, Sumanon \& Traiperm 5 (BKF); Nakhon Sawan, Bung Boraphet, 25 Nov. 1987, Vacharee 812 (BK); NORTH-EASTERN: Sakon Nakhon, Phu Phan National Park, 11 Mar. 1984, G. Murata et al s.n. (BKF); Khon Kaen, Kok Phu Taka, 30 Nov. 2003, C. Jaroenchai 31 (KKU); CENTRAL: Ang Thong, 28 Dec. 1929, Put 2585 (BM, K), 28 Feb. 1929, Put 2585 (BK); Nakhon Pathom, Mahidol University, Salaya, 24 Jan. 1999, J.F. Maxwell 9924 (L); Bangkok, Pak Kret, 6 Jan. 1914, A. Marcan 1604 (BM), 19 Oct. 1919, Kerr 3827 (BM, C, K), 30 Oct. 1923, Kerr s.n. (BK, BM), 5 Dec. 1926, Kerr 11103 (BK, BM, K); SOUTH-EASTERN: Rayong, 26 Nov. 1970, Lazarides 7943 (K, L); PENINSULAR: Chumphon, Paknam Chumphon, 12 Feb. 1968, Vacharapong 22 (BK); Surat Thani, Khun Talae Lake, 12 Jan. 1935, G. Seidenfaden 2300 (C); Nakhon Si Thammarat, Kiriwong, 17 Mar. 1951, Phloenchit 719 (BKF); Trang, Chao Chong, 29 Oct. 1984, J.F. Maxwell 84-358 (BKF), 12 Nov. 1990, K. Larsen, S.S. Larsen, A.S. Barfod, W. Nanakorn, W. Ueachirakan \& P. Sirirugsa 41285 (AAU, BKF); Yala, Yaha, Ban Lahm Lugah, 7 Nov. 1986, J.F. Maxwell 86-877 (BKF, L); Narathiwat, Su Ngi Paadee, Paa Wai, 10 Feb. 1988, C. Niyomdham 1660 (AAU, BKF, C, K, L); Toh Daeng, 16 Mar. 1993, P. Chantaranothai, K. Chayamarit, D. Middleton, J. Parnell \& D. Simpson 1192 (K), 4 Aug. 
1999, C. Niyomdham 5740 (BKF); Tak Bai, 18 Feb. 1984, C. Niyomdham 791 (BKF).

Distribution.- This species is widely distributed throughout tropical and warm temperate parts of the world.

Habitat and Ecology.- Growing in sand, clay or peat on open ground or in partial shade at the edge of swamps, canals, lakes, and waterholes from sea level to over $1800 \mathrm{~m}$ elevation; often a weed in paddy fields. Flowering from July until March.

Vernacular name.-Ya-sai.

Uses._- Fodder for livestock.

Conservation status. - This taxon occurs across a broad elevational range throughout Thailand, and has an EOO of $619907 \mathrm{~km}^{2}$ and an AOO of $168 \mathrm{~km}^{2}$. It was commonly encountered during our field work, and can colonise a wide variety of aquatic and moist habitats. We recorded it at 46 locations. Globally, it is extremely widespread and it is not presently facing any specific threat. We regard it as LC in Thailand.

Notes. - The Jamaican specimen at $S$ bears notes written in Swartz's hand and matches the original publication in all details, and should therefore be considered the holotype.

Retzius's type of Pharus ciliatus is not to be found at LD, as might be expected. Rather, the Koenig collection of this taxon at $\mathrm{C}$ matches the protologue and, since other Koenig types published by Anders Jåhan Retzius in his Observationes Botanicae are kept in $\mathrm{C}$, we believe this specimen to be a suitable choice for lectotype of that name.

2. Leersia stipitata Bor in Dansk Bot. Ark. 23(2): 147. 1965. Type: Thailand, Chanthaburi, Plain of Makam, 14 Jun. 1963, K. Larsen 10101 (holotype C!; isotypes BKF!, K!, fragm.). Fig. 4.

Annual herb. Culms slender, terete, glabrous, nodes hirsute. Leaf sheaths tight, striate, glabrescent on both sides, auricles acute; ligule c. $1 \mathrm{~mm}$ long, contracted at base; leaf blades c. $2 \times 4 \mathrm{~cm}$, glabrous. Inflorescence racemose, terminal, enclosed by sheath. Spikelets $5-6 \mathrm{~mm}$ long with a short pedicel c. $1 \mathrm{~mm}$ long, hirsute. Glumes absent. Lemma 4-5 mm long, boat-shaped, keeled, 5nerved, hirsute along keel, margins scabrous, apex tapering to a long, stout, straight awn $7-8.5 \mathrm{~mm}$ long. Palea 5.3-6 mm long, folded, shorter than the lemma, 2-nerved, scabrous apex. Anthers $1.2 \mathrm{~mm}$ long, yellow. Caryopsis not seen.

Thailand.- Only known from the type collection.

Distribution.-Endemic to Thailand.

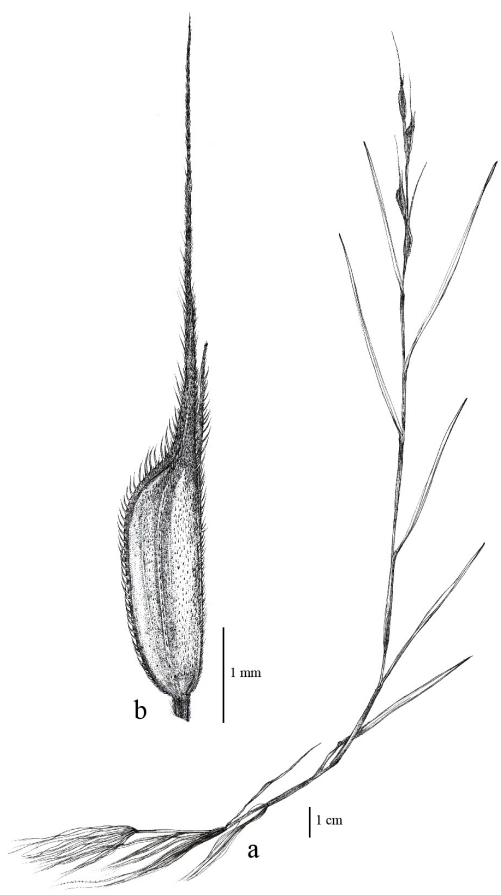

Fig. 4 Leersia stipitata Bor: (a) habit; (b) spikelet. Drawn by M. Norsaengsri.

Habitat and Ecology.- Growing by a waterhole at $50 \mathrm{~m}$ elevation. Flowering in June.

Conservation assessment.- This species has only been collected once and is therefore regarded as having an $\mathrm{AOO}$ of just $4 \mathrm{~km}^{2}$. As a strict Thai endemic, it is of global conservation importance. We revisited the type locality but were unable to find plants belonging to this taxon. At present, suitable habitat remains in the vicinity, offering hope that it may yet be rediscovered. However, the area is being gradually urbanized, posing a threat to the persistence of suitable habitat. Accordingly, we regard it as being CR (B1+2ab(ii,iii,iv,v); D).

\section{Oryza}

L., Sp. Pl.: 333. 1753; Bor, Grasses Burma, Ceylon, India \& Pakistan 601. 1960; Fl. China 22: 182. 2006. Type species: O. sativa L.- Padia Moritzi, Syst. Verz.: 103. 1845. Type species: P. meyeriana Zoll. \& Moritzi.

Perennial, rarely annual, tufted or stoloniferous herbs. Culms erect to ascending, sometimes branching at base. Leaf sheaths loose, not inflated, with well defined auricles; leaf blades linear to lanceolate. Inflorescence a panicle. Spikelets not flattened, bisexual, 1-fertile floret with 2 sterile lemmas. Glumes cup-shaped; sterile lemma present, 
Table 3 Key to species of Oryza in Thailand.

1. Sterile lemma more than half the length of the spikelet

1. Sterile lemma less than half the length of the spikelet

2. Ligule up to $5 \mathrm{~mm}$ long

3. Fertile lemma and palea with an irregularly granular surface

3. Fertile lemma and palea with a regularly granular surface

2. Ligule more than $5 \mathrm{~mm}$ long

4. Spikelets disarticulating; lemma and palea usually with purplish or dark red spots at the apex; fertile lemma long-awned; wild

4. Spikelets persistent; lemma and palea without purplish or dark red spots at the apex; fertile lemma acute, cuspidate or acuminate, awnless; cultivated
3. 0 . ridleyi

1. O. meyeriana

2. O. minuta
5. O. sativa

linear to lanceolate; fertile lemma boat-shaped, linear, elliptic, oblong-ovate or lanceolate, coriaceous. Palea smaller than lemma but similar in texture. Caryopsis terete.

A genus of 20 species in tropical and subtropical regions ${ }^{13}$; five species and one variety occur in Thailand, including $O$. sativa, a cultivated plant known throughout the range of the genus. See Table 3.

1. Oryza meyeriana (Zoll. \& Moritzi) Baill., Hist. Pl. 12: 166. 1893._ Padia meyeriana Zoll. \& Moritzi, Syst. Verz. 103. 1846. Type: Java, near Cibodas, 27 Nov. 1842, Zollinger 718 (holotype n.v.; isotypes BM!, G, K!, 2 sheets, L!, LE, P!, US). See Table 4.

a. O. meyeriana var. meyeriana Fig. 1E,F, Fig. 5.

Perennial, loosely tufted or shortly stoloniferous herb. Culms up to $60 \mathrm{~cm}$ tall, erect or ascending, sometimes branching at base; nodes terete, glabrous. Leaf-sheath slightly loose, glabrous, auricles well defined, ciliate; ligules $0.8-1.2 \mathrm{~mm}$ long; leaf-blades (1.2-)2-3.5 × 7-26 cm, lanceolateacute, rarely linear-lanceolate, margins scabrous, scabrid along nerves on both sides. Inflorescence panicle, narrowly contracted, erect. Spikelets $1(-3) \times(6-) 6.5-8 \mathrm{~mm}$, lanceolate to linear-lanceolate, light green, pale yellow or sometimes yellowish-brown. Glumes c. 0.5-0.8 mm long, cupshaped; sterile lemma 1-2.5 mm long, less than half the length of the spikelet, narrowly lanceolate to lanceolate; fertile lemma 1.8-2×(6-)6.5-

Table 4 Key to the varieties of $O$. meyeriana.

1. Leaves lanceolate, rarely linear-lanceolate; spikelet $1(-3) \times(6-) 6.5-8 \mathrm{~mm}$, lanceolate to linear-lanceolate a. var. meyeriana

1. Leaves linear to linear-lanceolate, rarely lanceolate; spikelet $2(-3) \times 5-6(-6.5) \mathrm{mm}$, oblong-elliptic

b. var. granulata

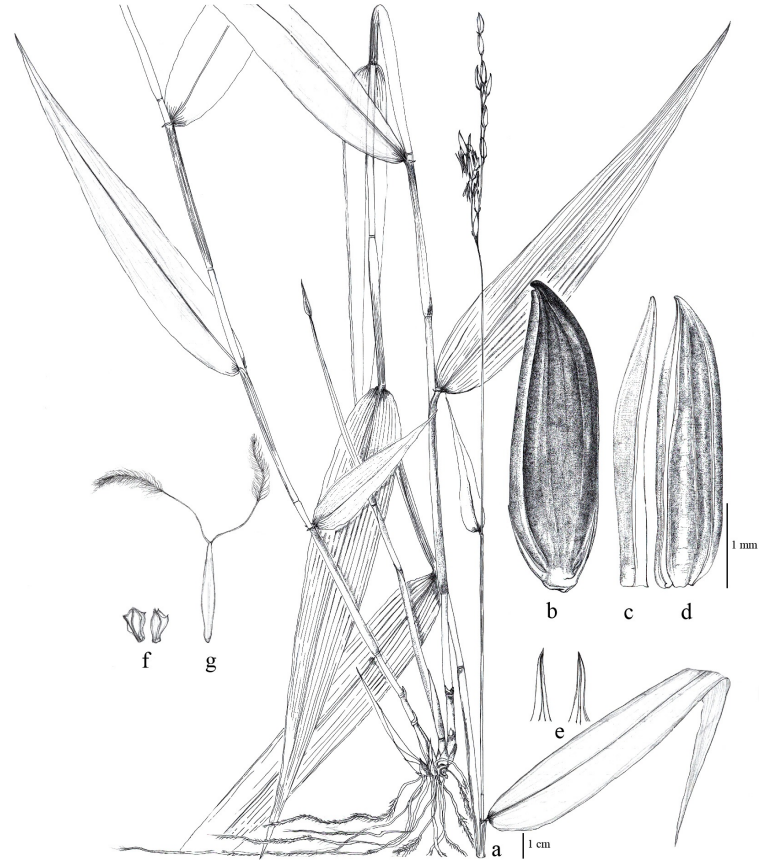

Fig. 5 Oryza meyeriana (Zoll. \& Moritzi) Baill. var. meyeriana: (a) habit; (b) lemma; (c,d) palea; (e) apex of palea; (f) lodicules; (g) pistil. Drawn by M. Norsaengsri.

$7.5 \mathrm{~mm}$, lanceolate, boat-shaped, coriaceous, irregularly granular surface, awnless. Palea c. $1.8 \times 6.5-$ $7.5 \mathrm{~mm}$, smaller and narrower than the lemma, similar in texture and surface, linear to linearlanceolate.

Thailand.- SOUTH-WESTERN: Prachuap Khiri Khan, Bang Sapan, 20 Aug. 1967, T. Shimizu \& A. Nalampoon T7771 (AAU); PENINSULAR: Chumphon, Ta Ngaw, 22 Jan. 1927, Kerr 11600 (K); Panom, 24 Mar. 1927, Kerr 12412 (K); Surat Thani, Bangbao, 7 Aug. 1955, T. Smitinand 2841 (BKF, K); Phatthalung, See Bahn Pote, Kao Boo-Kao Yah National Park, near Mat Cha cave, 15 Jun. 1986, J.F. Maxwell 86-387 (L); Khao Phu Khao Ya National 
Park, 31 Mar. 2012, Sumanon \& Traiperm 1 (BKF); Trang, Kantang, 31 May 1919, Md. Haniff \& Nur 4712 (K); Satun, Boripath waterfall, 19 Oct. 1991, K. Larsen, S.S. Larsen, C. Niyomdham, W. Ueachirakan \& P. Sirirugsa 42393 (AAU); Songkhla, Rattaphum, 16 Oct. 1984, J.F. Maxwell 84-329 (BKF).

Distribution.- Malaysia and Thailand.

Habitat and Ecology.- Occurring in shaded and semi-shaded areas along streams, among rocks and in wet soil, from sea level to $200 \mathrm{~m}$ elevation. Flowering from January until October.

Conservation assessment.- Nine locations were confirmed for this species in Thailand, all in the peninsular region, giving an EOO of $54416 \mathrm{~km}^{2}$ and an $\mathrm{AOO}$ of $36 \mathrm{~km}^{2}$. The subpopulations are small and scattered. This variety is not thought to have undergone decline, nor is it facing any specific threat at present. We assess it as LC in Thailand.

Notes. - In Thailand, this variety has only been found in the peninsular region.

b. O. meyeriana var. granulata (Nees \& Arn. ex G. Watt) Duist., Blumea. 32: 1. 1987.- O. granulata Nees \& Arn. ex G. Watt, Dict. Econ. Prod. India 5: 500. 1891. Type: India, Herb. Wight 2354 (holotype B destroyed; lectotype $\mathrm{K} !$, designated here; isolectotypes K!, K-W!, P!, U!).- O. meyeriana subsp. granulata (Nees \& Arn. ex G. Watt) Tateoka, Bot. Mag. Tokyo 75: 460. 1962, f. 3a. Fig. 6, Fig. 7A,B.

Perennial, loosely tufted or shortly stoloniferous herb. Culms up to $80 \mathrm{~cm}$ tall, erect or ascending, sometimes branching at base; nodes terete, glabrous. Leaf-sheath slightly loose, glabrous, auricles well defined, ciliate; ligules $0.8-1.2 \mathrm{~mm}$ long; leaf-blades $0.8-2.8 \times 7-22 \mathrm{~cm}$, linear to linear-lanceolate, acute, rarely lanceolate, margins scabrous, scabrid along nerves on both sides. Inflorescence panicle, narrowly contracted, erect. Spikelets $2(-3) \times 5-6(-6.5) \mathrm{mm}$, oblong-elliptic, light green or sometimes yellowish-brown. Glumes c. $0.5 \mathrm{~mm}$ long, cup-shaped; sterile lemma c. $0.5 \mathrm{~mm}$ long, less than a half length of the spikelet, narrowly lanceolate to lanceolate; fertile lemma 1.8-2 × 4.5$5.5(-6) \mathrm{mm}$, elliptic to oblong-ovate, boat-shaped, coriaceous, irregularly granular surface, awnless. Palea c. $1.5 \times 4.5-5.5 \mathrm{~mm}$, similar in texture and surface to the lemma, linear-lanceolate.

Thailand.- NORTHERN: Mae Hong Son, Mae Sariang, 12 Jul. 1968, K. Larsen, T. Santisuk \& E. Warncke 2382 (AAU, K, L); Chiang Mai, Doi Sutep, 6 Jul. 1910, Kerr 1241 (K); Wang Tao, 11 Jul. 1958, Th. Sørensen, K. Larsen \& B. Hansen 3980 (C, K); Sa Moeng, 13 Sep. 1958, Th. Sørensen, K. Larsen \&

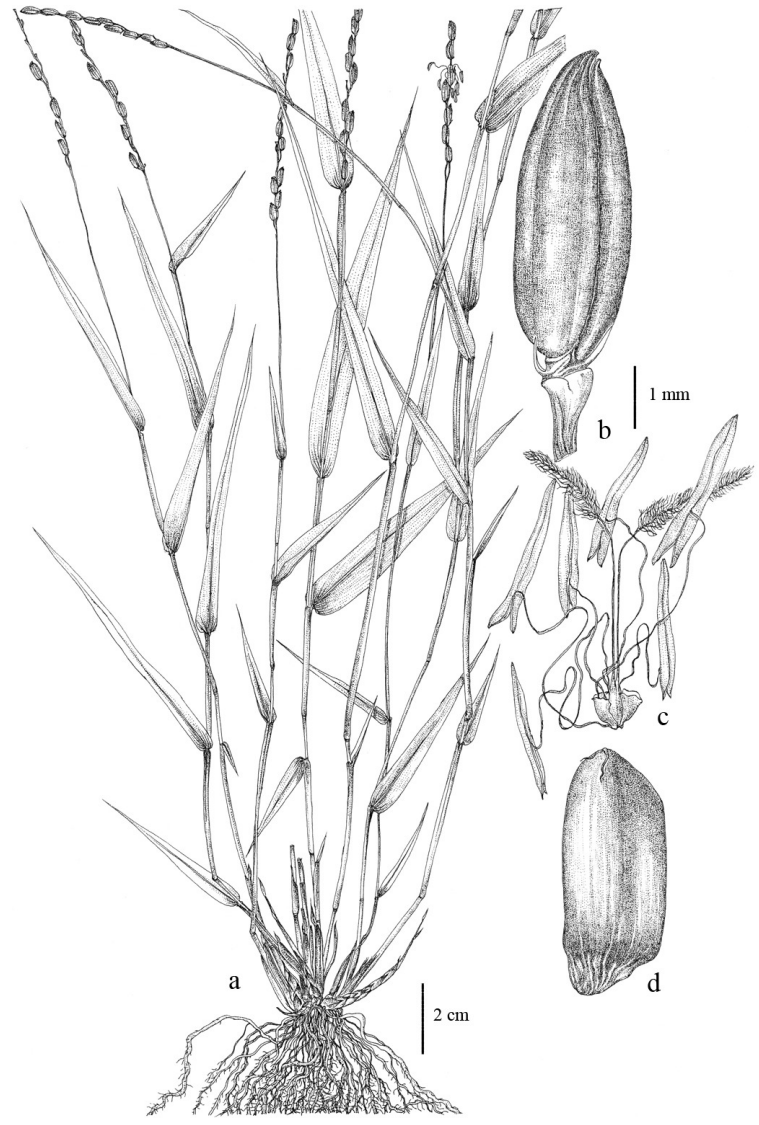

Fig. 6 Oryza meyeriana (Zoll. \& Moritzi) Baill. var. granulata (Nees \& Arn. ex G. Watt) Duist.: (a) habit; (b) spikelet; (c) lodicules, stamens, and pistils; (d) caryopsis. Drawn by M. Norsaengsri.

B. Hansen 4960 (C); Lampang, Ngao, 26 May 1954, T. Smitinand 1614 (K); NORTH-EASTERN: Nakhon Phanom, Dan Tan, 15 May 1932, Kerr 21464 (BK, K); SOUTH-WESTERN: Kanchanaburi, Sai Yok, 31 Jul. 1918, A. Marcan 2356 (K); Hin Dat, 5 Jul. 1926, Put 86 (BK, K); Sai Yok, 31 Jul. 1928, Put 1791 (BK, K); Ta Salao, 11 Jul. 1930, Kerr 19521 (BK, K); Wangka, 29 Apr. 1946, G. den Hoed 240 (BK, K, L); Sai Yok, 1 Jul. 1963, K. Larsen 10384 (C, K), 10484 (C, K); Sai Yok, 4 Dec. 1961, K. Larsen 8496 (C, K); Huay Bankau, 9 Nov. 1971, C.F. van Beusekom, C. Phengkhlai, R. Geesink \& B. Wongwan 3604 (K); SOUTH-EASTERN: Chanthaburi, Pong Nam Ron, 28 Nov. 1956, T. Smitinand 3652 (K); Soi Dao, 7 Jun. 1963, K. Larsen 9834 (C, K).

Distribution.- Also occurring in China, Myanmar, Laos, Cambodia, Malaysia, and Indonesia.

Habitat and Ecology.- Growing in moist areas in evergreen and deciduous forests, and in bamboo 

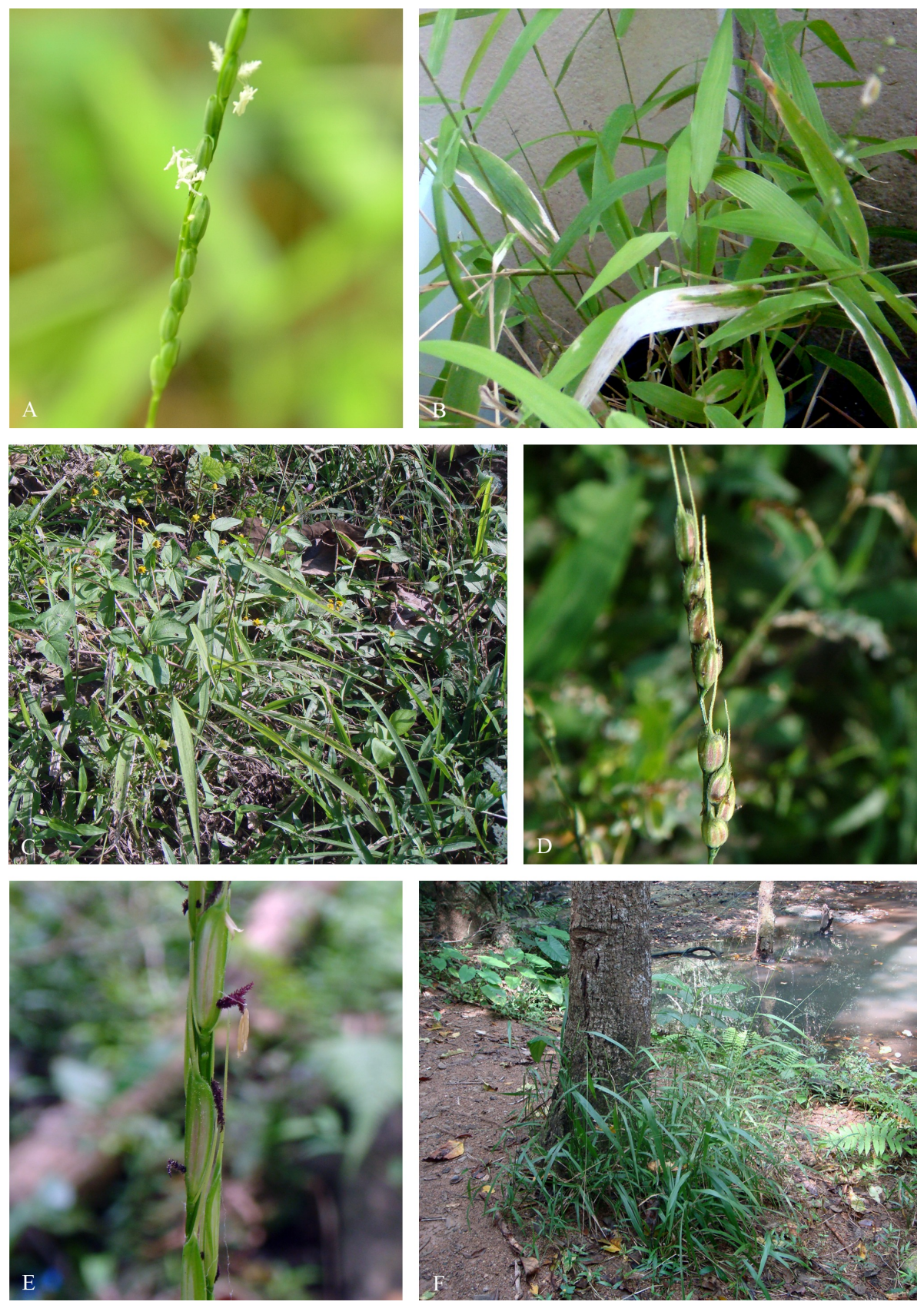

Fig. 7 (A,B) Oryza meyeriana (Zoll. \& Moritzi) Baill. var. granulata (Watt) Duistermaat: (A) inflorescence; (B) habit. (C,D) O. minuta J. Presl, (C) habit; (D) inflorescence. (E,F) O. ridleyi Hook. f., (E) inflorescence; (F) habit. (All photos: Paweena Traiperm).

groves, at elevations up to $1000 \mathrm{~m}$ altitude. Flowering all year round.

Vernacular name.-Khao-nok.

Conservation assessment.- This variety was recorded from 69 locations throughout Thailand, where it has an EOO of $532788 \mathrm{~km}^{2}$ and an AOO of $228 \mathrm{~km}^{2}$. It is a very common plant that forms small to medium-sized subpopulations in close proximity. It grows in a wide variety of habitats and is not thought to be subject to any particular threat. It is regarded as LC in Thailand.

Notes. - The type specimens of Synopsis glumacearum were acquired by B in 1855 but were subsequently destroyed. There are two Herb. Wight 


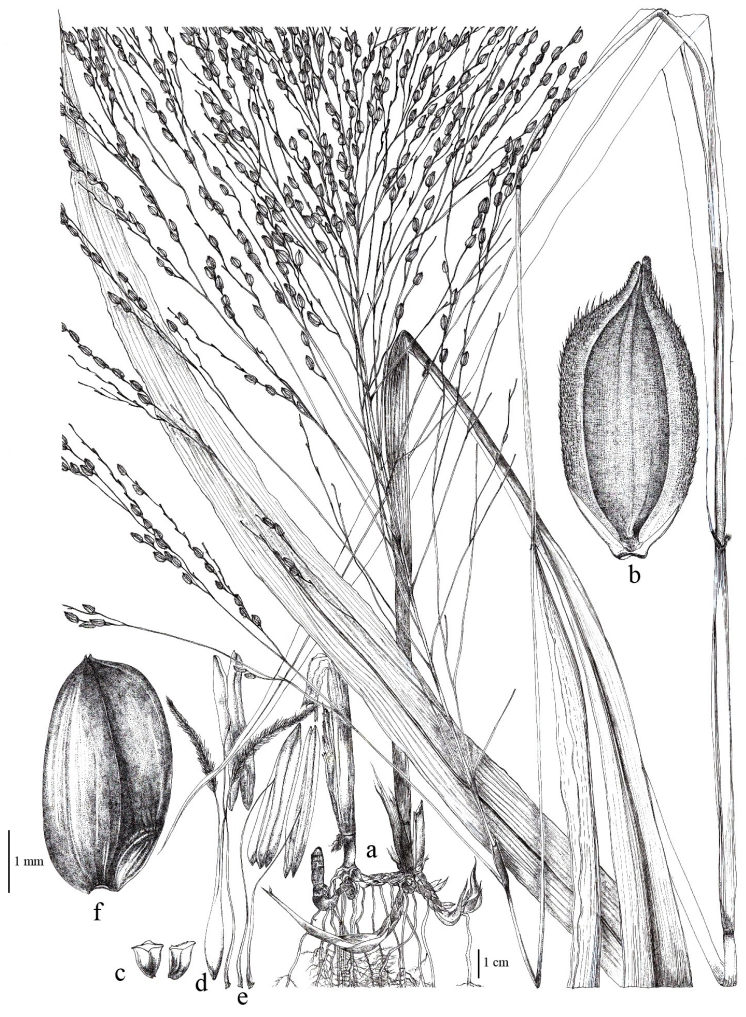

Fig. 8 Oryza minuta J. Presl: (a) habit; (b) lemma; (c) lodicules; (d) pistil; (e) stamens; (f) caryopsis. Drawn by M. Norsaengsri.

specimens in the $\mathrm{K}$ herbarium, but only one (Herb. Benthamianum; K000032065) is annotated with the name, and this one is also the better preserved. Accordingly, it is here selected as the lectotype.

2. Oryza minuta J. Presl, Reliq. Haenk. 1(4-5): 208. 1830. Type: Philippines, Luzon, Haenke s.n. (holotype PR, n.v.).-O. officinalis Wall. ex G. Watt, Dict. Econ. Prod. India 5: 501. 1891. Type: India, Sep./Oct. 1827, Wallich 8635 (holotype CAL, n.v.; isotypes K!, W).- O. latifolia Desv. var. silvatica A. Camus, Bull. Mus. Hist. Nat. 27: 456, pl. 18, f. 41. 1921. Type: Vietnam, Thu-Dầu-Môt, Budop, 28 Nov. 1919, Poilane 839 (holotype P!). Fig. 7C,D, Fig. 8.

Perennial, tufted or sometimes rhizomatous herb. Culms up to $1 \mathrm{~m}$ tall, erect; nodes glabrous. Leaf-sheath loose, terete, glabrous, auricles sometimes well defined, and with stiff hairs; ligules $1.5(-5) \mathrm{mm}$ long, with fimbriate margins; leafblades $2-3 \mathrm{~cm}$ wide and up to $80 \mathrm{~cm}$ long, narrowly lanceolate to lanceolate, apex acute, margins scabrous, rough with short hairs on both sur- faces. Inflorescence a panicle, loosely contracted, erect. Spikelets 2-2.5 ×5.5-6(-6.5) mm, oblong, light green or sometimes yellowish-brown. Glumes c. $0.5 \mathrm{~mm}$ long, cup-shaped; sterile lemma 1.3$2 \mathrm{~mm}$ long, less than a half length of the spikelet, lanceolate; fertile lemma 1.3-2 × 4.5-5.5(-6.5) $\mathrm{mm}$, oblong or elliptic, boat-shaped, coriaceous, regularly granulate on the surface, slightly hairy between the granules, apex acuminate, awned or awnless; if awned, c. 2.5-15 mm long. Palea c. $6.5 \mathrm{~mm}$ long, boat-shaped, half as broad as the lemma, similar in texture and surface.

Thailand.- SOUTH-WESTERN: Kanchanaburi, 28 Jan. 1961, K. Larsen 9330 (C, K); Sai Yok, 6 Dec. 1961, K. Larsen 8546 (C, K); Huay Menam Noi, 1 Jan. 1962, K. Larsen 9074 (C, K); Huay Bankau, 9 Nov. 1971, C.F. van Beusekom, C. Phengkhlai, R. Geesink \& B. Wongwan 3604 (C, L), 15 Nov. 1971, 3777 (C, K, L); Ratchaburi, Thung Kang Yang, 5 Jul. 1963, K. Larsen 10524 (C, K, L); CENTRAL: Saraburi, Khao Sam Lan, 22 Dec. 1988, Songkran/ DAVaughan 086/88/TNE135 (K); Bangkok, 31 Jan. 1920, Kerr 3975 (K), 31 Aug. 1920, Kerr 4440 (K), 25 Mar. 1923, Kerr 6772 (BK, K), 5 Oct. 1957, T. Tateoka W0002 (K).

Distribution.- Also occurring in Myanmar and China.

Habitat and Ecology. - Growing in shade in swampy areas in evergreen forest and in dry deciduous forest, from sea level to $400 \mathrm{~m}$ elevation. Flowering from June until March.

Vernacular name._-Ya-la-man.

Conservation assessment.- In Thailand, this species is known from a relatively restricted area in central and southwestern parts of the country, with an EOO of $91280 \mathrm{~km}^{2}$ and an $\mathrm{AOO}$ of $60 \mathrm{~km}^{2}$. Nevertheless, it is common, typically forming large populations. Some subpopulations in the southwest are likely to be contiguous with those in Myanmar. The species does not face any known threats in Thailand. It is regarded as LC in Thailand.

3. Oryza ridleyi Hook. f., Fl. Br. India 7(21): 93. 1897. Type: Malaya, Pahang, Pekan, Ayer Etam, 4 May 1890, Ridley 1178 (holotype K!; isotypes LE, SING!). Fig. 7E,F, Fig. 9.

Perennial, loosely tufted, stoloniferous herb. Culms up to $1 \mathrm{~m}$ tall, erect; nodes glabrous. Leafsheath slightly loose, nearly smooth, auricles well defined, ciliate; ligules $1(-5.5) \mathrm{mm}$ long; leafblades $1.2-1.5 \times 14-34 \mathrm{~cm}$, narrowly lanceolate or linear-lanceolate, upper surface scabrid, lower surface smooth or scabrid on nerves, margins scabrid. 


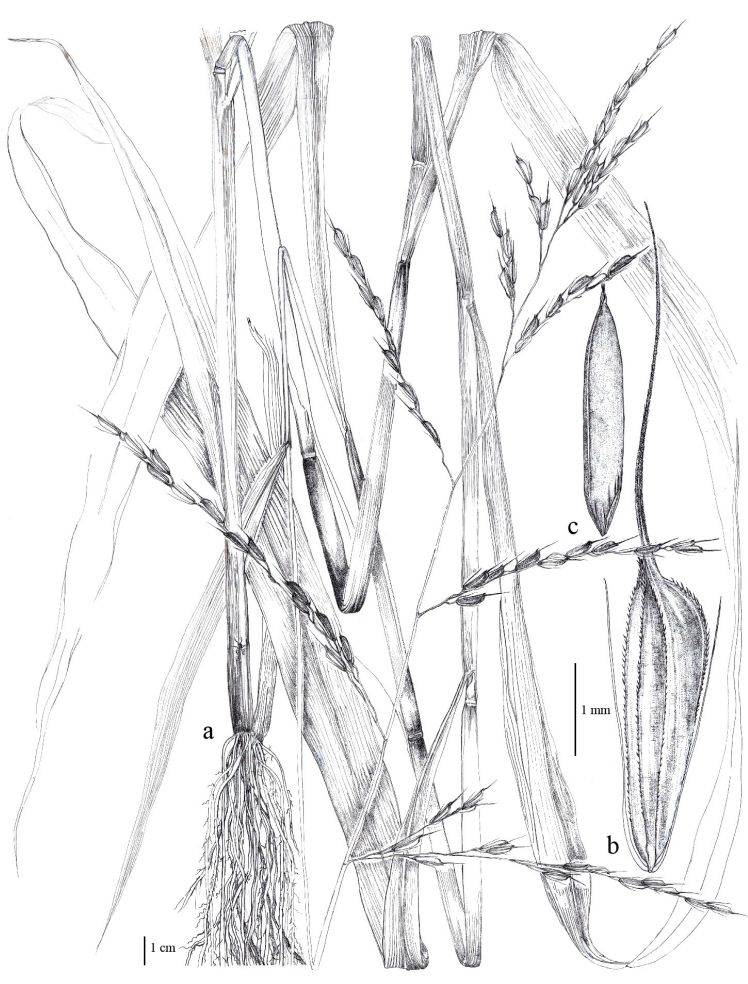

Fig. 9 Oryza ridleyi Hook. f.: (a) habit; (b) spikelet; (c) caryopsis. Drawn by M. Norsaengsri.

Inflorescence a panicle, loosely contracted, erect. Spikelets c. $2 \times(6.5-) 9-10 \mathrm{~mm}$, obovate-lanceolate. Glumes c. $0.3 \mathrm{~mm}$ long, cup-shaped; sterile lemma (5-)6.5-7.5 mm long, more than half the length of the spikelet, linear, apex acuminate; fertile lemma c. $1.7 \times(5-) 8-10 \mathrm{~mm}$, linear-lanceolate, boat-shaped, coriaceous, with a slightly irregularly granular surface; awn 5.5-12 mm long. Palea 7-10 mm long, much narrower and longer than lemma, similar in texture and surface.

Thailand.-CENTRAL: Saraburi, Sahm Lan waterfall, 23 Nov. 2012, Sumanon \& Traiperm 11 (BKF); Bangkok, 7 Oct. 1920, Kerr 4505 (K); SOUTH-EASTERN: Sa Kaeo, Aranya Pratet, 13 Sep. 1930, Put 3103 (BK, K); Chachoengsao, Krabin, Ban Keng, 7 Nov. 1930, Kerr 19780 (BK, K); Chanthaburi, Tha Mai, Khlong Tanot, 17 Oct. 1967, T. Smitinand 10421 (K); PENINSULAR: Nakhon Si Thammarat, Tha Sala, 13 Nov. 1971, T. Smitinand 11533 (C); Phatthalung, Kaw Khao, Th. Sørensen, K. Larsen \& B. Hansen 706 (C).

Distribution.- Malaysia and Thailand.

Habitat and Ecology.- Growing in shade along streams in dry evergreen forest, from sea level up to $100 \mathrm{~m}$ elevation. Flowering from December until
May.

Vernacular name.-Ya-khao-tham.

Conservation assessment.- This species was recorded from 11 locations and was frequently seen in the wild. In Thailand, its $\mathrm{EOO}$ and $\mathrm{AOO}$ are estimated as $176194 \mathrm{~km}^{2}$ and $44 \mathrm{~km}^{2}$, respectively. Each subpopulation seen in this study comprised one hundred or more individuals. It is not considered to be subject to any particular threaten. We regard it as LC in Thailand.

4. Oryza rufipogon Griff., not. Pl. Asiat. 3: 5. 1851., t. 144, f. 2. Type: Tim s.n. (holotype CAL, n.v.; isotype K!).- O. fatua Trin. var. longearistata Ridl., Fl. Malay. Penin. 5: 252. 1925. Type: Malacca, Batu Berendam, 15 Nov. 1917, SF 2825 (Burkill) (holotype SING!; isotype K!).-O. sativa forma spontanea Auct., ex Backer in Blumea, Suppl. 53. 1946. Type: Indonesia, Java, Jawa Barat, Tjibeber, C.A. Backer 13408 (lectotype L!).- O. nivara Sharma \& Shastry, Indian J. Genet. Pl. Breed. 25: 161. 1965., f. 2, 3. Type: India, Madhya Pradesh, Kandagarsh, 16 km S. of Raigarsh, 15 Oct. 1960, Sharmar 69 (holotype CAL, n.v.), Shamar 152 (topotype K!). Fig. 10.

Perennial, caespitose or stoloniferous herb. Culms up to $1 \mathrm{~m}$ long, decumbent and sometimes floating or ascending to erect, sometimes branching or rooting at base; nodes terete, glabrous. Leafsheath slightly loose, glabrous, auricles well defined, ciliate; ligules $6-21 \mathrm{~mm}$ long. Leaf-blades $0.3-1.5 \times 12-30 \mathrm{~cm}$, linear, apex acute, lower surface glabrous, upper surface scabrous on nerves or glabrous on both sides and scabrous on margins. Inflorescence a panicle, loosely contracted, erect. Spikelets 2.5-3 × (6.5-)7(-10) mm, oblong, rarely elliptic, yellow, sometimes with dark red or purple dots at the apex, disarticulating. Glumes 0.3-0.4 mm long, cup-shaped; sterile lemma c. $0.8 \times 1.5-3 \mathrm{~mm}$ long, less than half the length of the spikelet, lanceolate-acute; fertile lemma 1.5$2 \times(5.5-) 6-8 \mathrm{~mm}$, oblong, rarely elliptic-oblong, boat-shaped, coriaceous, with a regularly granular surface and with stiff hairs, apex with purplish or dark red spots, awn vary variable, $1.3-10 \mathrm{~cm}$ long, antrorsely scaberulous, stout, erect. Palea 0.8$1 \times(6-) 6.5-8.5(-10) \mathrm{mm}$, similar in surface and texture but longer and narrower than the lemma, linear-oblong, cuspidate or acuminate with purplish or dark red spot at the apex.

Thailand.- NORTHERN: Chiang Mai, Mae Taeng, 12 Nov. 1922, Kerr 6667 (BM, K); Muang, 11 Nov. 1986, C. Phengklai \& T. Smitinand 6041 


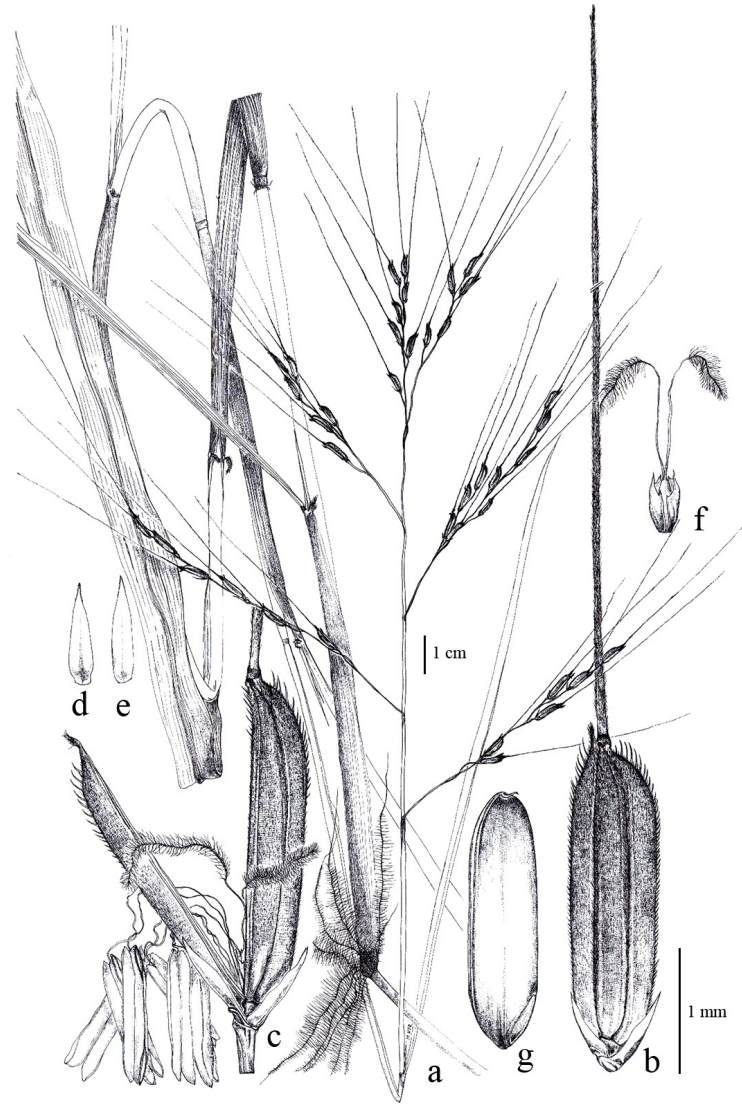

Fig. 10 Oryza rufipogon Griff.: (a) habit; (b) spikelet; (c) opened spikelet showing stamens and pistil; (d, e) sterile lemmas; (f) lodicules and pistil. Drawn by M. Norsaengsri.

(K); NORTH-EASTERN: Udon Thani, Nong Han, Ban Chiang, 28 Nov. 1988, Songkran/DAVaughan 086/88/TNE75 (K); Nong Khai, Muang, 28 Nov. 1988, Songkran/DAVaughan 086/88/TNE84 (K), Songkran/DAVaughan 086/88/TNE85 (K); Sakon Nakhon, Tha Rae, 28 Nov. 1988, Songkran/ DAVaughan 086/88/TNE64 (K); EASTERN: Nakhon Ratchasima, Sung Noen, Si Kiew, 24 Nov. 1988, Songkran/DAVaughan 086/88/TNE1 (K); Paktong Chai, 24 Nov. 1988, Songkran/DAVaughan 086/ 88/TNE2 (K); Chok Chai, Songkran/DAVaughan 086/88/TNE3 (K), Songkran/DAVaughan 086/88 /TNE6 (K), Songkran/DAVaughan 086/88/TNE8 (K); Buri Ram, Prakhon Chai, 25 Nov. 1988, Songkran/DAVaughan 086/88/TNE11 (K), 086/88 /TNE12 (K); Surin, Muang, 26 Nov. 1988, Songkran /DAVaughan 086/88/TNE27 (K); SOUTH-WESTERN: Kanchanaburi, Ban Kao, 11 Nov. 1961, K. Larsen 8136 (C, K); Phetchaburi, 9 Nov. 1926, Kerr 11088 (BK, K); CENTRAL: Ang Thong, 28 Dec.
1929, Put 2584 (BK, BM, K); Bangkok, 7 Dec. 1919, Kerr 3884 (BM, K); Bang Khen, 14 Nov. 1965, M. Tagawa \& K. Iwatsuki T.267 (K); SOUTH-EASTERN: Prachin Buri, 6 Nov. 1984, H.D. Catling s.n. (K); Chon Buri, Laemchabang, 22 Nov. 1927, D.J. Collins 1897 (K); Chanthaburi, 25 Nov. 1970, Lazarides 7460 (C, K, L); Khao Phra Bat, 27 Aug. 1972, K. Larsen, S.S. Larsen, I. Nielson \& T. Santisuk 32126 (AAU, K, L); PENINSULAR: Narathiwat, Su Ngai Paadee, Paa Wai, 10 Oct. 1988, C. Niyomdham 1939 (AAU, K).

Distribution.- Also occurring in Myanmar, China, Laos, and Malaysia.

Habitat and Ecology.- Occurring in moist places in forests, and a common weed of paddy fields.

Vernacular name.-Ya-khao-phi.

Conservation assessment.- This species was recorded from 66 locations across the entire country, giving an EOO of $641056 \mathrm{~km}^{2}$ and an AOO of $216 \mathrm{~km}^{2}$. It was frequently seen growing as a weed of paddy fields. Its subpopulations tend to be large and widely dispersed. It does not face any threat in Thailand. It is regarded as LC in Thailand.

5. Oryza sativa L., Sp. Pl. 1: 333. 1753; Bor, Grasses Burma, Ceylon, India \& Pakistan 605. 1960; Phan. Mono. Tom. 12: 184. 1980; Fl. Ceylon 8: 328. 1994; Fl. China 22: 183. 2006. Type: $H b$. Linné 460.1 (holotype LINN!). Fig. 11.

Annual or sometimes perennial, caespitose herb. Culms up to $1.5 \mathrm{~m}$ tall or more, erect to ascending, sometimes branching or rooting at nodes or at the base; nodes terete, glabrous. Leafsheath slightly loose, smooth with ciliate auricles; ligules $8-20 \mathrm{~mm}$ long; leaf-blades $0.8-2 \mathrm{~cm}$ wide and up to $30 \mathrm{~cm}$ long, linear-acute, scabrous on both sides and margins. Inflorescence a panicle, loosely contracted. Spikelets $2.5-3(-5) \times 7-10(-$ 12) $\mathrm{mm}$, oblong to oblong-ovate or slightly obovate, yellow, brownish or dark purple, persistent. Glumes c. $0.5 \mathrm{~mm}$ long, cup-shaped; sterile lemma 0.5$0.8 \times 1.5-3.5 \mathrm{~mm}$, lanceolate-acute, less than half the length of the spikelet; fertile lemma 2-2.5 $\times 6-$ $8.5(-11) \mathrm{mm}$, oblong, rarely elliptic-oblong, boatshaped, coriaceous, with a regularly granular surface and with stiff hairs, apex without purplish or dark red spots, awnless, apex acute, acuminate or cuspidate, up to $5 \mathrm{~mm}$ long, or sometimes occasionally awned. Palea $0.8-1 \times 6-9(-10.5) \mathrm{mm}$, similar in surface and texture but longer and narrower than the lemma, linear-oblong, acute, mucronate, without purplish or dark red spots at the apex. 


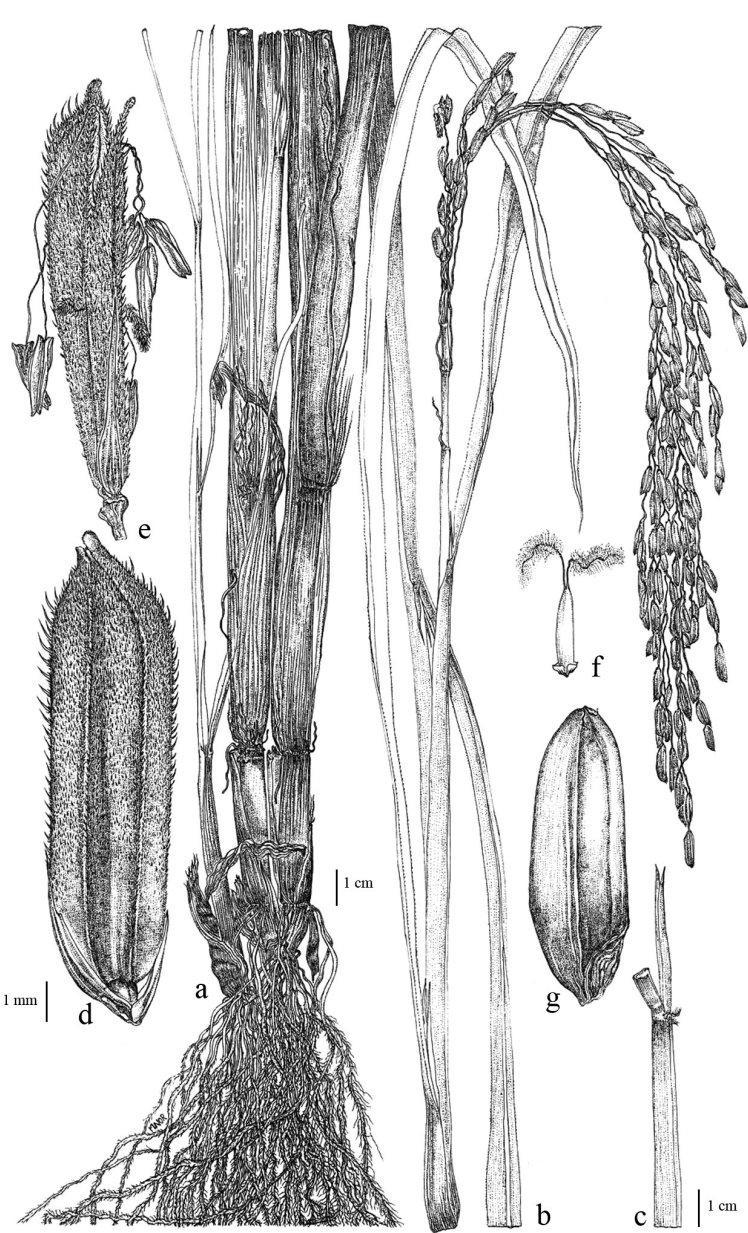

Fig. 11 Oryza sativa L.: (a) habit; (b) inflorescence; (c) ligule; (d) spikelet; (e) opened spikelet showing stigmas and anthers; (f) lodicules and pistil; (g) caryopsis. Drawn by M. Norsaengsri.

Thailand.- NORTHERN: Chiang Mai, Doi Sutep, 18 Oct. 1914, Kerr 3419 (BM, K), 3420 (BM, K), 3421 (BM), 3422 (BM, K); 11 Nov. 1914, 3454 (BM, K), 3456 (BM, K); 12 Nov. 1914, 3457 (BM, K), 3460 (BM, K); NORTH-EASTERN: Kalasin, 13 Oct. 1990, P. Chantaranothai \& John Parnell 90/675 (K); CENTRAL: Bangkok, Pak Nam, 25 Feb. 1923, Kerr s.n. (BM); PENINSULAR: Surat Thani, Khao Sok, 30 Nov. 1986, C. Niyomdham 1281 (C, K, L); Narathiwat, Tak Bai, Kuu Chum, 9 Apr. 1988, C. Niyomdham \& W. Ueachirakan 1793 (AAU, C, K, L), 1794 (AAU, C, K, L), 1795 (C, K), 1796 (AAU, C, K).

Distribution.- Widely cultivated in tropical, subtropical and temperate Asia, and elsewhere around the world.

Habitat and Ecology.- A domesticated cultivar. Vernacular name.-Khao.
Uses.- Grown for its nutritious grain.

Conservation assessment.- A conservation assessment was not conducted because this is an artificially abundant, man-made cultivar.

\section{Zizania}

L., Sp. Pl. 2: 991. 1753; Bor, Grasses Burma, Ceylon, India \& Pakistan 606. 1960; Phan. Mono. Tom. 12: 184. 1980; Fl. China 22: 186. 2006. Type species: Z. aquatica, Prop. Brit. Bot. 188. 1929.

Annual, aquatic herbs. Leaf sheaths inflated, spongy; leaf blades linear lanceolate or lanceolate. Inflorescence a panicle. Spikelets unisexual, narrowly cylindric, not flattened, 1-floret. Glumes absent. Lemma membranous, 5-nerved, keeled, awned. Palea smaller and shorter than the lemma, 3-nerved. Grains terete.

The genus of 4 species distributed in eastern Asia including Indo-China ${ }^{16}$; one species occurs in southern Thailand as a cultivated vegetable.

1. Zizania latifolia (Griseb.) Turcz. ex Stapf in Bull. Misc. Inform. Kew 1909: 385. 1909; Bor, Grasses Burma, Ceylon, India \& Pakistan 606. 1960; Phan. Mono. Tom. 12: 185. 1980; Fl. China 22: 186. 2006. Type: Russia: Davuria, in lacubus ad confluxum fluviorum Schilka et Argun, 1833, Turczaninow s.n. (holotype LE!; isotypes L!, LE several duplicates).- Hydropyrum latifolium Griseb., in Ledeb., Fl. Ross. 4: 466. 1853.-Z. aquatica var. latifolia (Griseb.) Kom., Fl. Manschur. 1: 261. 1901. Fig. 12.

Annual aquatic herb, up to c. $1 \mathrm{~m}$ tall. Leaf blade c. 3-4×70-90 cm, apex aristate, margins entire, parallel veined and with a prominent midrib, continuous with the leaf sheath and demarcated by a collar; flag leaf below the panicle, smaller than normal leaves. Inflorescence c. $45 \mathrm{~cm}$ long, a large panicle, terminal, erect, numerous spikelets, unisexual florets, the lower spikelets of panicle consist of male florets, the upper spikelets consist of female florets. Male floret $1.5-2 \mathrm{~cm}$ long, longer than female spikelets, long awned from tip of the lemma, 3-4 cm long. Female floret 1-1.5 cm long, awned from the tip of the lemma, awn $0.5-1 \mathrm{~cm}$ long. Caryopsis dark brown.

Thailand.-CENTRAL: Bangkok, Bangkhen, 10 Sep. 1974, Umpai 508A (BK).

Distribution.- In addition to Thailand, this species occurs in India, Myanmar, China, Japan, Laos, Cambodia, and Malaysia.

Habitat and Ecology.- A cultivated crop.

Vernacular name.-No-mai-nam. 


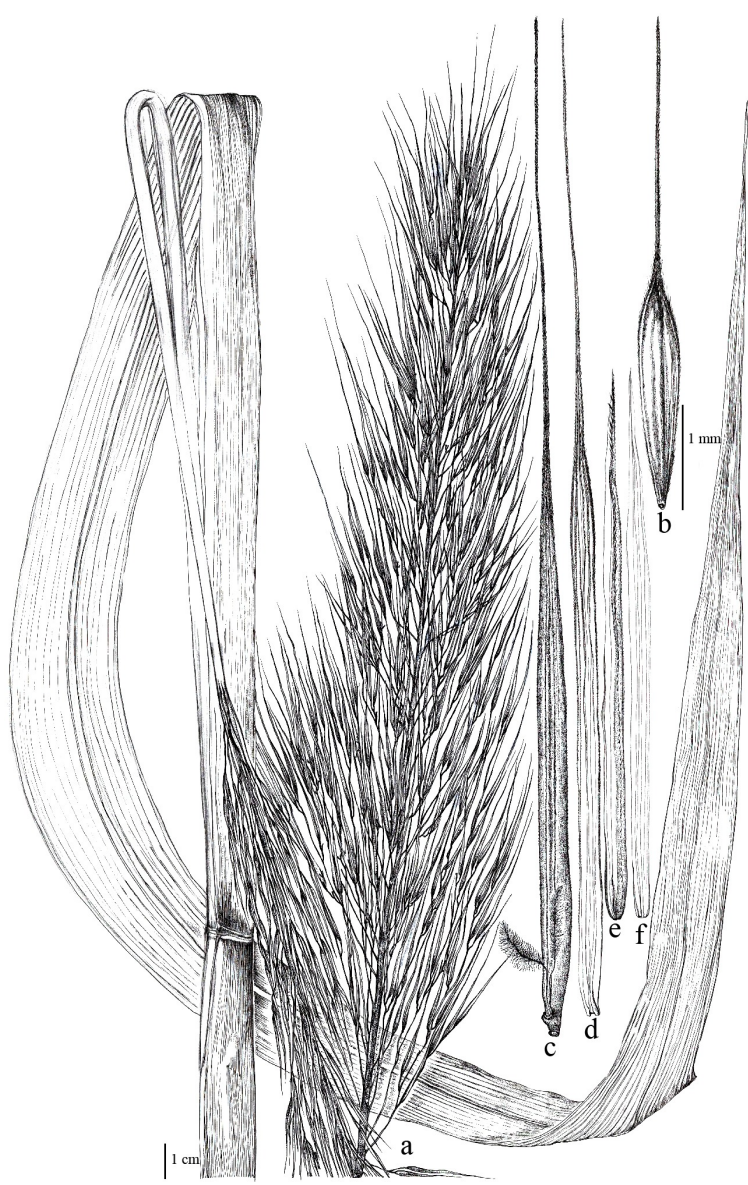

Fig. 12 Zizania latifolia (Griseb.) Turcz. ex Stapf: (a) habit; (b) spikelet; (c, d) lemma; (e, f) palea. Drawn by M. Norsaengsri.

Uses.- Cultivated for its edible young shoots.

Conservation assessment.- A conservation assessment was not conducted because this is an artificially abundant, man-made cultivar.

Acknowledgements: We would like to thank the directors and curators of the following herbaria for providing herbarium specimens in this study: AAU, BK, BKF, BM, $\mathrm{C}, \mathrm{K}, \mathrm{K}-\mathrm{W}, \mathrm{KKU}, \mathrm{L}$, and QBG. The authors are grateful to the anonymous referees for valuable comments to improve our manuscript. The first author wishes to thank the Development and Promotion of Science and Technology Talented Project of Thailand (DPST) for funding this study while she was at Kew in 2008-2010. Dave Simpson is gratefully acknowledged for supporting this work. This study project was supported by Mahidol University. Phanom Sutthisaksopon, Teerawat Srisuk, Woranart Thammarong, and Haruthai Hemadhulin are thanked for providing colour photos.

\section{REFERENCES}

1. Soreng RJ, Peterson PM, Romashenko K, Davidse G, Zuloaga FO Judziewicz EJ, Filgueiras TS, Davis JI, Morrone O (2015) A worldwide phylogenetic classification of the Poaceae (Gramineae). J Systemat Evol 53, 117-37.

2. Clayton WD, Renvoize SA (1986) Oryzeae. In: Clayton WD, Renvoize SA (eds) Genera Graminum: Grasses of the World, Kew Publishing, Royal Botanic Gardens, London, pp 70-5.

3. Liu L, Phillips SM (2006) Oryzeae. In: Zhengyi W, Raven PH, Deyuan H (eds) Flora of China 22, Science Press, Beijing and Missouri Botanical Garden, St. Louis, pp 182-7.

4. Bor NL (1960) The Grasses of Burma, Ceylon, India and Pakistan (excluding Bambuseae), Pergamon Press, Oxford.

5. Clayton WD, Davidse G, Gould F (1994) Oryza. In: Dassanayake MD (ed) Flora of Ceylon 8, Smithsonian Institution, Washington, pp 326-30.

6. Hooker F (1900) Gramineae. In: Trimen H (ed) $A$ Handbook to the Flora of Ceylon 5, Dulau, London, pp 113-319.

7. Duistermaat H (1987) A revision of Oryza (Gramineae) in Malesia and Australia. Blumea 32, 157-93.

8. Na Nakorn W (1996) Gramineae (Poaceae) in Thailand, Queen Sirikit Botanic Garden, Chiang Mai.

9. Sumanon P, Traiperm P (2013) An investigation of lemma micromorphology in Thai Oryzeae (Poaceae). Sci Asia 39, 567-73.

10. IUCN (2001) IUCN Red List Categories and Criteria: Version 3.1. IUCN species Survival Commission, IUCN, Gland and Cambridge.

11. Bachman S, Moat J, Hill AW, de la Torre J, Scott B (2011) Supporting Red List threat assessments with GeoCAT: geospatial conservation assessment tool. ZooKeys 150, 117-26.

12. IUCN (2003) Guidelines for Application of IUCN Red List Criteria at Regional Levels: Version 3.0. IUCN Species Survival Commission, IUCN, Gland and Cambridge.

13. Clayton WD, Vorontsova MS, Harman KT, Williamson $\mathrm{H}$ (2006 onwards). GrassBase - The Online World Grass Flora, www.kew.org/data/grasses-db.html.

14. Lazarides M (1980) The tropical grasses of Southeast Asia (excluding bamboos). In: Cramer J (ed) Phanerogamarum maographiae tomus XII, J. Cramer, Vaduz, pp 1-225.

15. Turner IM (2013) Robinson a century on: the nomenclatural relevance of Roxburgh's Hortus Bengalensis. Taxon 62, 152-72.

16. Terrell EE, Peterson PM, Reveal JL, Duvall MR (1997) Taxonomy of North American species of Zizania (Poaceae: Zizaniinae). SIDA Contrib Bot 17, 533-49. 